\title{
Project-based inquiry-science: An innovative learning for thinking, teaching and assessing science-physics
}

\author{
Nurita Apridiana Lestari ${ }^{\text {a. * }}$, Eko Hariyono ${ }^{\text {b }}$, Dwikoranto Dwikoranto ${ }^{c}$, Binar Kurnia Prahani ${ }^{\text {, }}$, \\ Utama Alan Deta ${ }^{\mathrm{a}}$ \\ Universitas Negeri Surabaya. Jl. Ketintang, Surabaya, 60231, Indonesia \\ a nuritalestari@unesa.ac.id; b ekohariyono@unesa.ac.id; ' dwikoranto@unesa.ac.id; \\ d binarprahani@unesa.ac.id, utamadeta@unesa.ac.id \\ * Corresponding Author.
}

Received: 23 November 2021; Revised: 22 December 2021; Accepted: 20 January 2022

\begin{abstract}
Project-based Inquiry Science (PjBI-Science) is one of the embodiments of innovative learning designed for students to have abilities like scientists and to experience various investigative methodologies, which include experimentation, modelling, simulation, and data analysis in the fields of earth science, life science, and physical sciences. Not only beneficial for students, but PjBI-Science also facilitates teachers to be able to design detailed learning processes and conduct assessments according to students' thinking skills and abilities, both individually and in groups. This study aims to identify the characteristics and find the benefits of implementing PjBI-Science learning. The research method used is a systematic review with a meta-aggregation method that summarizes the results of research related to $\mathrm{PjBI}$-Science qualitatively. Based on the literature review results to identify the characteristics of the implementation of PjBi-Science, conclusions were obtained regarding the benefits of implementing learning. For students, it can improve the quality of abilities in the natural science field and accommodate the learning needs to optimize thinking skills, while for teachers, it can holistically provide alternative teaching styles in an innovative way and conduct an effective assessment of the activities and cognitive abilities of students.

Keywords: Project-based Inquiry-Science; Innovative learning; meta-aggregation
\end{abstract}

How to Cite: Lestari, N. A., Hariyono, E., Dwikoranto, D., Prahani, B. K., \& Deta, U. A. (2022). Project based inquiry-science: An innovative learning for thinking, teaching and assesing science-physics. Momentum: $\quad$ Physics Education Journal, 6(1), 86-92. https://doi.org/10.21067/mpej.v6i1.6254

\section{Introduction}

The main objective in learning material in the natural sciences lies in the ability and skills to relate the theory to the implementation in real life. Various applications of innovation models have been carried out to improve the ability of students, as prospective teachers, in designing effective learning to be applied in teaching in schools later. Both learning models focus on increasing aspects of knowledge and aspects of thinking skills and working scientifically. Therefore, the relationship between teacher and student becomes very important during the learning process. The professional relationship between students and teachers is shaped by experience and thus demonstrates professional growth, empowerment, and a substantial increase in self-confidence (Tsybulsky \& MuchnikRozanov, 2019).

The provision of experience can be realized through learning that can accommodate the capability to think and work independently in giving assignments. The implementation of the assignment method that can be used to improve scientific performance is through project-based learning (Miller et al., 2021; Panasan \& Nuangchalerm, 2010). Preparation of project assignments can help 
students to think independently develop solutions, creativity, and self-regulation skills (Anazifa \& Djukri, 2017; Guo et al., 2020).

Implementing project-based learning does not mean only giving project assignments to students. Characteristics of a good project are the ability to develop and construct student knowledge in accordance with the scientific field being occupied (Ninan, 2020), so that projects given to students must be regulated by focusing more on inquiry-based learning. Inquiry learning will be very appropriate if applied in the field of science because it can train students' scientific performance (Fitzgerald et al., 2019; Gillies \& Rafter, 2020; Larroder, 2021; Longa, 2021; Riga et al., 2017; Tarwiyani et al., 2019). Therefore, project-based learning that can also collaborate with the inquiry process can be implemented by carrying out project-based inquiry science (PjBI-Science). PjBIScience is a learning model designed to maximize the development of scientific thinking and working skills (Harrer et al., 2013; Kolodner et al., 2010; Thys et al., 2016). Project-Based Inquiry Science (PjBIScience) learning is a collaboration between Project-Based Learning and Inquiry models by integrating aspects of science in the application of learning (Kolodner et al., 2010). Collaboration between these models is expected to improve the quality of the learning process and outcomes, which include aspects of knowledge, attitudes, and scientific skills.

$\mathrm{PjBI}$-Science is a learning system that can develop the ability to think systematically, especially in solving a problem in the field of science or physics. This learning system was developed by Kolodner et al. (2010) to facilitate science learning activities for middle-aged students, further applied by (Harrer et al., 2013) by involving students to identify and review the PjBI-Science learning process. Based on the research results, it is known that PJBI-Science learning has a good impact on their project workability, but they still need closer assistance, especially in carrying out each stage of learning. So it can be suggested that researchers who will apply PjBI-Science in learning should be able to provide individual assistance for their students. Therefore, the purpose of this research study on PjBI-Science was conducted to identify the characteristics of PjBI-Science and to find the benefits of implementing this learning, especially for students and teachers in the field of natural science.

\section{Methods}

This study uses a systematic review method, which is a research method to identify, evaluate, and interpret all relevant research results related to certain topics (Xiao \& Watson, 2019). A systematic review was carried out using the synthesis method of relevant qualitative research results to gain a deeper understanding (meta-synthesis) by using a summarizing technique (meta-aggregation) (Lockwood et al., 2015). The summary is carried out on scientific articles that discuss the topic of PjBI-Science, which is then elaborated to produce a conceptual framework. Clearly, the synthesis process is shown in Figure 1.

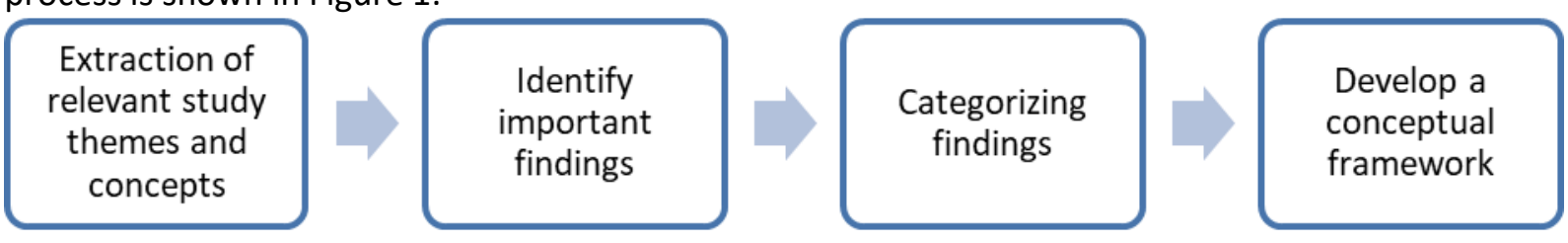

Figure 1. Systematic Review Research with Meta-aggregation

\section{Results and Discussion}

Project-based Inquiry Science is a learning design that was developed with the aim of providing real experience to students about investigative methodology in science learning. Thus, students will be accustomed to conducting investigations and reasoning on scientific knowledge (Kolodner et al., 2010). Based on the results of the review of the article on PjBI-Science, interesting findings were obtained, which can be summarized in aspects related to students' thinking skills, learning design for teachers, and the process of assessing student activities. 


\section{Improving Thinking Skills}

All types of learning designs are developed to improve the quality of the learning process and outcomes, especially for students. Project-based learning prioritizes the quality of the results of assignments creatively arranged by students to be able to improve their higher thinking skills (Anazifa \& Djukri, 2017; Guo et al., 2020; Ninan, 2020; Panasan \& Nuangchalerm, 2010). It is different from inquiry-based learning, which prioritizes the quality of the process of achieving understanding by students through learning activities that have been carried out (Fitzgerald et al., 2019; Gillies \& Rafter, 2020; Khalaf et al., 2018; Larroder, 2021; Riga et al., 2017). Therefore, if the two are combined into a complete learning design. It is hoped that the entire process and learning outcomes of students can be accommodated to the maximum level (Hasni et al., 2016; Ong et al., 2016; Eng Tek et al., 2017; Lau et al., 2017; Thi Thuy et al., 2018; Johnson et al., 2019; Chu et al., 2021; Himes et al., n.d.; Hoe Ng et al., 2021). So, through this PjBI-Science learning design, students can improve their thinking processes and outcomes in the realm of science. Students can identify the knowledge, make predictions, conduct investigations, obtain experimental data, make conclusions, solve problems, and create projects as a form of implementation of their thinking processes.

Students are guided to experience the thought process by analyzing an event and then modelling it in a form that is understood. For example, based on Figure 2a, students were asked to make an appropriate model as a form of project and then explain it (Figure 2b). Figure 2a shows a child throwing garbage from the top-down window where under the window, there is a rotating wheel system. The garbage disposal event is carried out simultaneously with throwing the ball into a moving racket system. In the end, both the trash and the ball will collide with the wheel system and racket system. This is a form of energy transfer event due to a collision. This phenomenon is proposed to stimulate students' thinking skills in analyzing the physical processes that occur and then making project designs to explain and model the results of the analysis. The assessment will be made based on the results of the suitability of the analysis project that has been made by students. The activity is an excerpt from the material "Energy from Waste" (Table 1) in the Physics Unit.

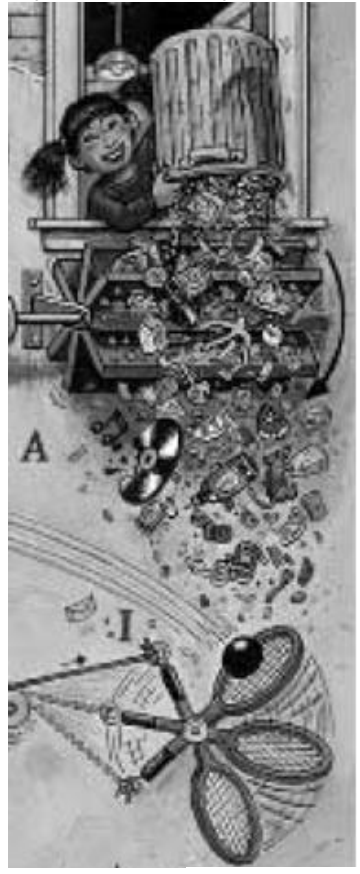

a

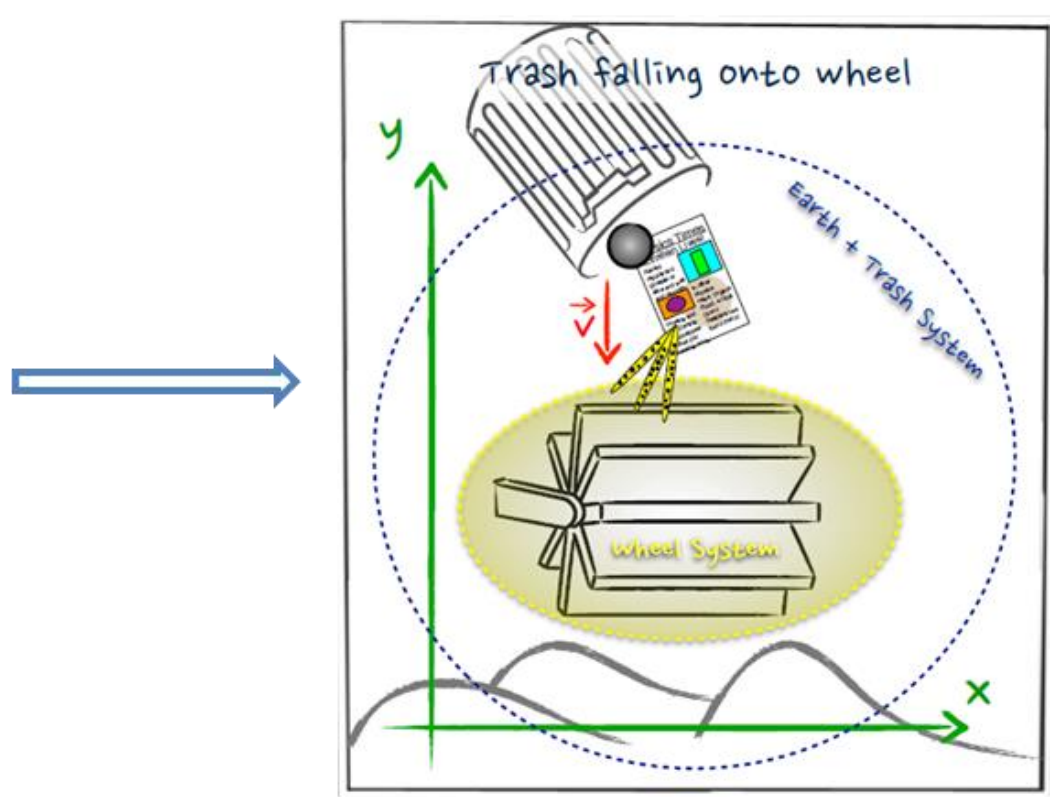

b

Figure 2. Phenomenon Modelling of "Energy from Trash" (source: Harrer et al., 2013), 2a) the process of throwing trash from a window and $2 \mathrm{~b}$ ) Physics model of the energy transfer process

\section{Teaching with PjBI-Science}

Before carrying out the practice of learning using PjBI-Science, the teacher must prepare the design of the activities to be carried out according to the relevant material. In the PjBI-Science 
learning design that has been developed and tested in schools, science materials and appropriate learning indicators have been prepared. The Table 1 is a list of teaching materials that can be taught using PjBI-Science.

Table 1. Description of Units in the Field of PBIS Scientific Studies

\begin{tabular}{|c|c|c|}
\hline Earth Science Units & Life Science Units & Physics Science Units \\
\hline Digging In & Animals in Action & Diving into Science \\
\hline $\begin{array}{l}\text { Design activities include } \\
\text { experiments, simulations and } \\
\text { modelling as methods of } \\
\text { investigation with Rock and } \\
\text { Volcano materials }\end{array}$ & $\begin{array}{l}\text { The design of the activity focuses on } \\
\text { observing and interpreting data on } \\
\text { the material of Body Structure and } \\
\text { Function and animal behaviour }\end{array}$ & $\begin{array}{l}\text { Design of physics experiment } \\
\text { activities with motion and gravity } \\
\text { materials }\end{array}$ \\
\hline Planetary Forecaster & $\underline{\text { Good Friends and Germs }}$ & Moving Big Things \\
\hline $\begin{array}{l}\text { Activity design includes prediction } \\
\text { and decision making with material } \\
\text { about Planet }\end{array}$ & $\begin{array}{l}\text { The activity design focuses on } \\
\text { preventing friends from getting sick } \\
\text { due to bacteria, viruses and human } \\
\text { body systems }\end{array}$ & $\begin{array}{l}\text { Design of problem-solving } \\
\text { activities related to force, effort, } \\
\text { and pulley materials }\end{array}$ \\
\hline Earth Structures and Processes & Living Together & Air Quality \\
\hline $\begin{array}{l}\text { Design activities for the materials } \\
\text { of Layers of the earth, } \\
\text { earthquakes, and topographic } \\
\text { maps through a problem-solving } \\
\text { process }\end{array}$ & $\begin{array}{l}\text { Design activity focuses on the } \\
\text { analysis of the fields of genetics, } \\
\text { evolution and genetic engineering }\end{array}$ & $\begin{array}{l}\text { Design activities in the form of } \\
\text { observing air quality and } \\
\text { providing recommendations for } \\
\text { solutions }\end{array}$ \\
\hline Underground City & $\underline{\text { Genetics }}$ & $\underline{\text { Vehicles in Motion }}$ \\
\hline $\begin{array}{l}\text { Design discussion activities for } \\
\text { geological materials }\end{array}$ & $\begin{array}{l}\text { Design activity focuses on the } \\
\text { analysis of the fields of genetics, } \\
\text { evolution and genetic engineering }\end{array}$ & $\begin{array}{l}\text { Activity design is in the form of } \\
\text { designing a motion system by } \\
\text { applying Newton's laws }\end{array}$ \\
\hline Astronomy & I, Bio & Energy from Trash \\
\hline $\begin{array}{l}\text { Activity design includes } \\
\text { identification of celestial bodies } \\
\text { and their movements }\end{array}$ & $\begin{array}{l}\text { Design of discussion activities and } \\
\text { in-depth introduction to the } \\
\text { processes of the human body }\end{array}$ & $\begin{array}{l}\text { Design activities that prioritize } \\
\text { the ability to design natural } \\
\text { resource conservation systems }\end{array}$ \\
\hline
\end{tabular}

The main principle in implementing the PjBI-Science model is the existence of a Big Challenge/Question, Project Board, and Learning Set. Big Challenge/Question is an activity to identify new material by presenting problems or events related to the material to be studied. Project Board is a tool in facilitating and checking things that have been done and learned. The Project Board can also be used as a track record to assist in answering the main problem (big challenge/question). An example of a project board is as follows (Table 2).

Table 2. Example of Buiding a Project Board Design for Vehicles in Motion Unit (Kolodner et al., 2010)

Project Board for "Vehicles in Motion"

Instruction: Design and build a vehicle that will go straight, far, and fast, and carry a load

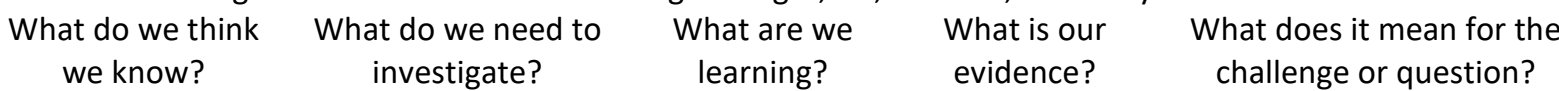

(answers)

(answers)

(answers)

(answers)

(answers)

The next stage is "Learning Sets", which includes activities such as asking questions, seeking answers, sharing answers, describing the results, and then applying the conclusions to the big challenge/question. More clearly, the activities carried out at the learning set stage is as follows. (a.) Understanding the Question or Challenge; (b) Investigate/Explore; (c) Read; (d) Design and Build; (e) Explain and Recommend; (f) Reflect

As an advanced stage, there are activities to be able to discuss, and present project results in a class or group format (Kolodner et al., 2010). These activities include investigation expo (discussing in 
small groups to create a project in more detail based on the results of investigation data), idea briefing (explaining the results of project assignment discussions in class forums so that input can be given), and solution showcase (reporting complete project results).

The concept that characterizes PjBI-Science learning lies in the project assignments given, namely the association of material with the application of the scientific field of science. Therefore, the PjBI learning model will be very relevant if it is applied in science learning, especially physics learning in schools.

\section{Assessing Science-Physics}

Assessment is also an important component during the learning process, especially projectbased learning (Panasan \& Nuangchalerm, 2010). The teacher must clearly determine the desired learning achievement indicators suitable to the student's condition. Assessment can be focused on aspects of students' skills and cognitive abilities or even a combination of the two. PjBI-Science has a choice of assessment processes, namely individually and in groups. Individual assessment, for example, can be done by giving homework assignments to review the material that has been delivered by the teacher or preparing interesting ideas from the implementation of teaching materials that will be discussed at the next meeting written in the form of "Learning Journal". At the same time, group assessments are carried out during learning activities in a class by participating in experiments, discussions, and presentations.

In general, the assessment process carried out is not much different from other learning assessments. But the assessment must be emphasized aspects of students' understanding of the material and involvement in each stage of learning. Therefore, each student is required to make a "project board" so that teachers can easily check the achievement of learning indicators for each student.

\section{Conclusion}

This literature review focuses on studies to identify the characteristics and effectiveness in the application of this PjBi-Science learning design in the context of learning, teaching, and assessing for learners in the natural sciences. The summary results from the literature review that discuss projectbased learning and inquiry-based learning in the natural science field show high effectiveness in their implementation, especially if they can collaborate as offered by PjBI-Science learning.

Based on the results of the literature review that has been carried out, it can be concluded that (1) PjBI-Science can be implemented in an educational process that prioritizes the quality of students' abilities in the natural science field because learning is indeed designed for that field; (2) PjBI-Science can accommodate students' needs to learn individually and in collaborations to maximize thinking skills and optimize student contributions in the classroom; (3) it provides context for teachers to be able to teach in an innovative and structured way; and (4) teachers can conduct effective assessments of students' activities and cognitive abilities. Finally, the result will still depend on teachers' and students' commitment to carrying out learning according to the prioritized needs.

\section{References}

Anazifa, R. D., \& Djukri, D. (2017). Project-based learning and problem-based learning: Are they effective to improve student's thinking skills? Jurnal Pendidikan IPA Indonesia, 6(2), 346. https://doi.org/10.15294/jpii.v6i2.11100

Chu, K. W. S. (2009). Inquiry project-based learning with a partnership of three types of teachers and the school librarian. Journal of the American Society for Information Science and Technology, 60(8), 1671-1686. https://doi.org/10.1002/ASI.21084

Fitzgerald, M., Danaia, L., \& McKinnon, D. H. (2019). Barriers inhibiting inquiry-based science teaching and potential solutions: perceptions of positively inclined early adopters. Research in Science Education, 49(2), 543-566. 
Gillies, R. M., \& Rafter, M. (2020). Using visual, embodied, and language representations to teach the $5 \mathrm{E}$ instructional model of inquiry science. Teaching and Teacher Education, 87, 102951.

Guo, P., Saab, N., Post, L. S., \& Admiraal, W. (2020). A review of project-based learning in higher education: Student outcomes and measures. International Journal of Educational Research, 102(April), 101586. https://doi.org/10.1016/j.ijer.2020.101586

Harrer, B. W., Flood, V. J., \& Wittmann, M. C. (2013). Students talk about energy in project-based inquiry science. AIP Conference Proceedings, 1513(1), 162. https://doi.org/10.1063/1.4789677

Himes, M., Spires, H., Krupa, E., \& Good, C. (n.d.). An Interdisciplinary Project-Based Inquiry Global Process.

Khalaf, B. K., Zin, M., \& Bt, Z. (2018). Traditional and inquiry-based learning pedagogy: a systematic critical review. International Journal of Instruction, 11(4), 545-564.

Kolodner, J. L., Krajcik, J. S., Edelson, D. C., Reiser, B. J., \& Starr, M. L. (2010). Project-based inquiry science $^{T M}$. Project-Based Inquiry Science ${ }^{T M}$ (PBIS).

Larroder, A. C. (2021). Addressing the challenges and scaffolding of inquiry-based teaching on secondary school students' efficacy in conducting scientific inquiry. In Science Education Research and Practice from Japan (pp. 45-61). Springer.

Lau, W. W. F., Lui, V., \& Chu, S. K. W. (2017). The use of wikis in a science inquiry-based project in a primary school. Educational Technology Research and Development, 65(3), 533-553. https://doi.org/10.1007/s11423-016-9479-9

Lockwood, C., Munn, Z., \& Porritt, K. (2015). Qualitative research synthesis: methodological guidance for systematic reviewers utilizing meta-aggregation. JBI Evidence Implementation, 13(3), 179187.

Longa, M. K. (2021). Instrumen performance assessment berbasis kerja laboratorium untuk mengukur keterampilan proses dan sikap ilmiah. Measurement in Educational Research (Meter), 1(1), 39-51. https://doi.org/10.33292/meter.v1i1.109

Miller, E. C., Severance, S., \& Krajcik, J. (2021). Motivating teaching, sustaining change in practice: Design principles for teacher learning in project-based learning contexts. Journal of Science Teacher Education, 32(7), 757-779.

$\mathrm{Ng}, \mathrm{C}$. H., \& Adnan, M. (2021). The effect of using project-based inquiry learning (PIL) stem module in topic space among year one students. Psychology and Education Journal, 58(1), 4718-4726. https://doi.org/10.17762/pae.v58i1.1631

Ninan, J. (2020). Online naturalistic inquiry in project management research: directions for research. Project Leadership and Society, 1, 100002.

Ong, E. T., Ayob, A., Ibrahim, M. N., Adnan, M., Shariff, J., \& Ishak, N. (2016). The effectiveness of an in-service training of early childhood teachers on stem integration through project-based inquiry learning (PIL). Journal of Turkish Science Education, 13(special), 44-58. https://doi.org/10.12973/tused.10170a

Owensby, J. N. (2006). Exploring the development and transfer of case use skills in middle-school project-based inquiry classrooms [Georgia Institute of Technology]. https://smartech.gatech.edu/bitstream/handle/1853/10525/owensby_jakita_n_200605_phd. pdf

Panasan, M., \& Nuangchalerm, P. (2010). Learning outcomes of project-based and inquiry-based learning activities. Online Submission, 6(2), 252-255.

Riga, F., Winterbottom, M., Harris, E., \& Newby, L. (2017). Inquiry-based science education. In Science education (pp. 247-261). Brill Sense.

Tarwiyani, T., Ibrohim, I., \& Mahanal, S. (2019). Penerapan pembelajaran sains berbasis inquiry based learning terintegrasi nature of science dalam meningkatkan keterampilan metakognitif siswa. Jurnal Pendidikan: Teori, Penelitian, Dan Pengembangan, 4(10), 1341. 
https://doi.org/10.17977/jptpp.v4i10.12841

Thi Thuy, H., Dieu Thuy -Ha, H., Hoe Ng, C., Adnan, M., Chee, K., \& Pinang, P. (2018). Integrating STEM education through Project-Based Inquiry Learning (PIL) in topic space among year one pupils. IOP Conference Series: Materials Science and Engineering, 296(1), 012020. https://doi.org/10.1088/1757-899X/296/1/012020

Thys, M., Verschaffel, L., Van Dooren, W., \& Laevers, F. (2016). Investigating the quality of projectbased science and technology learning environments in elementary school: a critical review of instruments. Studies in Science Education, 52(1), 1-27.

Tsybulsky, D., \& Muchnik-Rozanov, Y. (2019). The development of student-teachers' professional identity while team-teaching science classes using a project-based learning approach: A multilevel analysis. Teaching and Teacher Education, 79, 48-59.

Xiao, Y., \& Watson, M. (2019). Guidance on conducting a systematic literature review. Journal of Planning Education and Research, 39(1), 93-112. 